\title{
Comparative Study of the Importance of School Record Management on Pupils' Learning Progress in Public Primary Schools in Kwara State, Nigeria
}

\author{
Aminat Ozohu Aburime ${ }^{1}$ \& Zainab Olanihun Ambali ${ }^{2}$ \& Olabisi Fadekemi Adesina ${ }^{3}$ \& Tunde \\ Toyese Oyedokun ${ }^{4}$
}

${ }^{1}$ Department of Arts Education, Faculty of Education, University of Ilorin, Ilorin, Nigeria

${ }^{2 \& 3}$ Library Department, University of Ilorin, Ilorin, Nigeria

${ }^{4}$ Department of Library and Information Science, Faculty of Communication and Information Sciences, University of Ilorin, Ilorin, Nigeria

Correspondence: Tunde Toyese Oyedokun, University of Ilorin, Ilorin, Nigeria.

Email: toyex4eternity@gmail.com

DOI: $10.53103 /$ cjess.v1i2.15

\begin{abstract}
The study set out to make a comparison of the significance of school record management on the learning progress of schoolchildren in public primary schools. Objectives are set to investigate what records are presently kept in public primary schools in Kwara State, examine qualities expected of school record management, ascertain the effectiveness of record-keeping on learning progress of pupils and identify challenges associated with records keeping in public primary schools in Kwara State. A descriptive survey research design was espoused for the study and school heads and class teachers constitute the unit of analysis. Questionnaire and observational checklist serve as instruments for data collection. The report of findings indicated that the surveyed seven public primary schools keep the same statutory and non-statutory records and none kept punishment register. On the quality of a good school record management, top in the ranking are information on the records should be accurate, reliable and timely. With the student performance record, it is evidence that parents, teachers and other educational stakeholders can easily keep track of students' learning progress to effect positive change if need be. Result of findings on constraints to effective record management in Kwara State, Nigeria, pinpointed majorly on two challenges, one of which is that most records are old, due for weeding as a result of lack of preservation measures put in place and also that records are still stored manually in paper files, shelves and cabinets.
\end{abstract}

Keywords: School Records, Record Management, Learning Progress, Public Primary Schools, Kwara State, Nigeria

\section{Introduction}

School records are official documents, books, or files that contain essential information on students' actions and performance as well as events and occurrences that took place in school. Such records are kept and preserved by head teachers or principals, 
class teachers, counselors and school administrative staff for reference purposes. Some of the school records include staff record books, the logbook, visitors' book, inventory books, attendance register, punishment registers, students' report sheet and many more. The purpose of record-keeping and management is to ensure accurate and proper records of students, learning progress and information on schools' activities are documented for future planning and administrative use. Schools keep an account of each pupil on its roll which contains all the necessary information about the pupils, which help to judge the learning progress of pupils, their strength and weakness and help teachers and parents, can render to bring about desirable changes. The pupil's academic records form the bedrock on which the guidance/counselor shall offer professional advice.

The national policy on education in Nigeria requires that school administrators keep proper records of the school activities and students' progress and performance, to ensure the smooth running of the school. The extent to which the school administrators succeed in carrying out their responsibility depends on some factors and one of them has to do with the records that they are expected to keep. Records that are statutorily specified by law are referred to as statutory records while, other necessary records not stipulated by law are known as non-statutory records (Nigerian Educational Research and Development Council, 2004). Statutory records are those prescribed by country education law and so must be kept by every school and should be produced on demand by constituted authorities. Statutory records include admission register, attendance register, the scheme of work, school time-tables, logbooks, financial records, continuous assessment records, and many more, while the non-statutory records are of private use to the school and this includes punishment book, school calendar, staff minute book, supervision reports file and others (Amie-Ogan \& Tagbo, 2020; Koko \& Nwiyi, 2019).

School records occupy a strategic position in school administration and as such helps in effective planning and implementation of the appropriate course of action, thereby introducing proper monitoring of school activities tasks. Records are important because they serve as a major information tool that sustains the school and aid in achieving educational goals and objectives. Be that as it may, not all information can be considered as a record until it satisfy such characteristics as genuine authenticity, that is, the information such record give is true, correct and original and most importantly comprehensive, accessible and secured. Records keeping and management, on the other hand, is the application of systematic and scientific control, exercised over the distribution, utilization, retention, storage, retrieval, protection, preservation and final disposition of all types of records within the school.

Primary education according to the National Policy on Education (2013) is the basic education given in elementary schools to children between the ages of 6-12years. Formal education begins with primary education and the duration is six years. Primary education is compulsory and free under the Universal Basic Education (UBE) program 
introduced by former President Olusegun Obasanjo on September 30th, 1999. The two basic functions of primary schools are to prepare the child for life and to allow those with the necessary background to proceed to the secondary school level. Amadi (2014) emphasized that primary education is the underlying supporting structure that form the bedrock or foundation upon which higher education are created. This underscores the importance of good academic performance for every child that undergoes primary school education in Nigeria. Students' performance records furnished comprehension into student learning progress that help guide parents and teachers in making crucial decisions regarding learning needs of students. Likewise, attendance records that help teachers and school management to maintain accountability for students' safety. Attendance records are often sent home to parents on students' report sheets/cards, it provides a great deal of information about students' performance, and when students are not doing well in school, a well-kept record can help offer insights.

\section{Statement of the Research Problem}

Despite the importance of record-keeping in the achievement of educational objectives and that of students' academic achievement, these school records seem not to be adequately managed by the school management. There seems to be low priority attention to the record-keeping of school activities and that of students' learning progress. This low priority manifested in missing records of students' academic progress reports, which led to management falsification of records. Students' learning progress has variedly been referred to in the literature as academic achievement and scholastic functioning. Meanwhile, the academic performance of students is a key feature in education (Rono, 2013). It is considered to be the nerve center around which the whole education system revolves. Buttressing the forgoing was Narad and Abdullah (2016) that correspondingly stated the obvious that success or failure of the school succeed the academic performance of students. Signh, Malik and Signh (2016) also argued that the academic performance of students has a direct impact on the socio-economic development of a country. Contributing factors to the enhancement of students' academic performance have received much attention from researchers and educators around the world (such as: Signh, Malik \& Sign, 2016; Ali, Haider, Munir, Khan \& Ahmed, 2013; Farooq, Chaudhry, Shafiq \& Behanu, 2011). These researchers found that several factors contribute to improvement in the academic performance of students.

For instance, Ali, Haider, Khan and Ahmed (2013) established that everyday study hours, social-economic status of parents/guardians and age are factors that remarkably influence student's leaning and academic performance. Similarly, Narad and Addullah (2016) and Farooq, Chaudhry, Shafiq and Behanu (2011) also found the economic status

of parents, their academic background and encouragement as factors that influence 
student's academic performance. Correspondingly, Singh, Malik and Singh (2016) found guidance from parents and teachers, communication skills, and learning facilities as determinants of student's academic performance. Other authors have also found that age, gender and parents' level of education affect academic performance (Khan, Iqbal \& Tasneem, 2015; Eshetu, 2014). Findings from previous studies are combination of student's home background, teacher factors and/or environmental, psychological and socioeconomic factors. It should be noted that these findings differ across countries at different academic levels and the subjects involved. But this study focuses on the importance of record-keeping on the learning progress of public primary school students in Kwara State, Nigeria. On the account of accurate documentation, the government will be able to carry out proper supervision of schools to ensure that government policy on education is strictly adhered to and completely followed.

\section{Objectives of the Study}

The specific objectives for the study are to:

1. Investigate what records are presently kept in public primary schools in Kwara State;

2. Examine qualities expected of school record management;

3. Ascertain the effectiveness of record-keeping on the academic performance of pupils in public primary schools in Kwara State; and

4. Identify those challenges associated with record-keeping in public primary schools in Kwara State.

\section{Review of Relevant Related Literature}

Record keeping is a vital responsibility of the school administrator and the complexity in school administration, its constraints, contingencies, and other difficulties make record keeping a necessity that has become indispensable role in the day-to-day activities of the school system (Ololube, 2011). School administrators rely on the short and long-term data captured in records to make effective decisions (Alabi, 2017). Succinctly, Ibara (2010) asserts that without records there can be no accountability. It was further maintained that quality performance, task accomplishment, and measurable outcomes are increasingly important responsibilities, all of which depend on the accessibility of usable records. Without records, it is almost impossible to determine what is responsible for what and for whose actions we are to hold individuals accountable. According to Ololube (2013), school records can thus be said to comprise all existing and accessible records, books, files and other documents containing useful information that relates to what goes on in the school system. These records may also be in the form of reports, letters, memos, pictures, 
films, journals, diaries, and so on.

Uzoho (2006) investigated the record-keeping practices of secondary school principals in the Umuahia Education Zone of Abia state and the problems associated with the keeping of these records, the study reported that urban and rural secondary school teachers in the Umuahia Education zone kept records such as admission register, attendance register, staff minutes book, school time table, school accounts book, academic records of students and copies of schools rules and regulations in their schools. Recordkeeping practices include principals delegating the keeping of day-to-day administrative records to senior teachers, recording events as they occur in the appropriate records booklets, keeping accurate custody of record materials and books in the offices, checking every item of information in the records before appending their signatures. More so, there is no significant difference between opinions of urban and rural secondary schools, teachers with regards to the administrative practices that characterize the keeping of records in secondary schools in the Umuahia Education zone of Abia State. Connection between Uzoho's (2006) study and the current study is embedded in the capacity of school head in embracing effective school records management practices.

Records constitute a storehouse of useful information to students, parents, teachers, school heads and employers on the background activities and progress of staff and students. The keeping of records furnishes not only parents but teachers, principals with data on the activities, problems and achievements of their students. But the literature on general knowledge of school record keeping and management is scanty and the current study presents the importance of school record-keeping to students' academic performance. It also sensitized school management on the need to keep a necessary and reliable date or information for accurate documentation. On the account of accurate documentation, the government will also be able to carry out proper supervision of schools to ensure that government policy on education is strictly adhered to and completely followed, and finally, the study contributes to the existing and non-existing body of knowledge that forms the basis for further studies.

\section{Methodology}

The research design adopted for this study is a descriptive survey with public primary school teachers in Kwara State constituting the unit of analysis. The sapling technique is multi-stage that first involves cluster random selection of seven local government areas to represent the three senatorial districts in the state from the sixteen local government areas in Kwara State. Then, followed by purposive sampling, a deliberate sampling where the sample is based on knowledge of an individual concerning the subject matter, hence, head teachers/headmistress and class teachers from seven local government areas that cut across the three senatorial districts in Kwara State were selected for the 
sample. A questionnaire and observational checklist were adopted for this study. The questionnaire was administered to class teachers and school heads while the observation checklist was filled with the help of the school heads.

For content validity of the instruments, it was given to three researcher experts in the Educational Management Department of the University of Ilorin, Ilorin, Nigeria. Their observation and correction were considered when the final draft is made. On the reliability of the questionnaire, the instrument was twice administered to a group of 30 teachers from three schools that are not part of the research work in Ilorin South Local Government Area. The two sets of scores were then correlated using Pearson's Product Moment Correlation Coefficient procedure with a Cronbach Alpha calculation score of 0.72 , which was considered reliable enough.

Researchers inform the respondents of the purpose and objectives of the study, also the nature of the study was explained to them. After a brief introduction, respondents were given sufficient time to read and attend to the question raised. Upon completion the instrument for data collection was retrieved, the anonymity of each respondent is ensured at all stages. Data collected were analyzed using tabular presentations of transcriptions of respondents' responses using descriptive statistics of frequency count, percentage and mean score.

\section{Analysis and Interpretations of Data}

All administered questionnaires were returned representing a $100 \%$ response rate, from a survey of 108 public primary school teachers in Kwara State, Nigeria.

Table 1: Demographic characteristic of the respondent's N (108)

\begin{tabular}{lllll}
\hline S/N & $\begin{array}{l}\text { Demographic } \\
\text { Variable }\end{array}$ & Demographic Data & Frequency & $\begin{array}{l}\text { Percent- } \\
\text { age }\end{array}$ \\
\hline 1 & Gender & Male & 48 & $44 \%$ \\
\cline { 3 - 5 } & Female & 60 & $56 \%$ \\
\cline { 2 - 5 } & Total & Below 20 & 108 & $100 \%$ \\
\hline 2 & Age & $21-30$ & 4 & $4 \%$ \\
\cline { 3 - 5 } & & $31-40$ & 37 & $40 \%$ \\
\cline { 3 - 5 } & & $41-50$ & 11 & 13 \\
\hline & Total & Place of & Community LGEA Pri- & $10 \%$ \\
\hline & Work & mary School, Ganmo, & 19 \\
\hline
\end{tabular}




\begin{tabular}{|c|c|c|c|c|}
\hline & & \multicolumn{3}{|l|}{$\begin{array}{l}\text { Ifelodun Local Govern- } \\
\text { ment Area. }\end{array}$} \\
\hline & & Baptist LGEA Primary & 15 & $14 \%$ \\
\hline & & School, Surulere, Ilorin & & \\
\hline & & West Local Government & & \\
\hline & & Area. & & \\
\hline & & Gaa-Akanbi LGEA Pri- & 14 & $13 \%$ \\
\hline & & mary School, Gaa- & & \\
\hline & & Akanbi, Ilorin South Lo- & & \\
\hline & & cal Government Area. & & \\
\hline & & Ayedaade Community & 17 & $16 \%$ \\
\hline & & LGEA Primary School, & & \\
\hline & & Offa Local Government & & \\
\hline & & Area. & & \\
\hline & & Agbede-Shere LGEA Pri- & 16 & $15 \%$ \\
\hline & & mary School, Agbede, & & \\
\hline & & Moro Local Government & & \\
\hline & & Area. & & \\
\hline & & KLGA Demonstration & 13 & $12 \%$ \\
\hline & & Primary School, Kaima & & \\
\hline & & Local Government Area. & & \\
\hline & & Community Primary & 14 & $13 \%$ \\
\hline & & School, Apata-Kajola, & & \\
\hline & & Irepodun Local Govern- & & \\
\hline & & ment Area. & & \\
\hline & Total & & 108 & $100 \%$ \\
\hline 4 & Duty Post & Head Teacher & 7 & $6 \%$ \\
\hline & & Assistant Head Teacher & 7 & $6 \%$ \\
\hline & & Class Teacher & 96 & $88 \%$ \\
\hline & Total & & 108 & $100 \%$ \\
\hline 5 & Qualification & $\begin{array}{l}\text { Nigeria Certificate of Ed- } \\
\text { ucation }\end{array}$ & 68 & $63 \%$ \\
\hline & & Bachelor of Education & 23 & $21 \%$ \\
\hline & & Postgraduate Diploma in & 10 & $9 \%$ \\
\hline & & Education & & \\
\hline & & Master in Education & 7 & $7 \%$ \\
\hline & Total & & 108 & $100 \%$ \\
\hline 6 & & Less than 10 years & 58 & $54 \%$ \\
\hline
\end{tabular}




\begin{tabular}{llll}
\hline Teaching Ex- & 11 to 20 years & 19 & $17 \%$ \\
\cline { 2 - 4 } perience & 21 to 30 years & 16 & $15 \%$ \\
\cline { 2 - 4 } & 31 and above & 15 & $14 \%$ \\
\hline Total & & 108 & $100 \%$
\end{tabular}

Source: Field Survey

Table 1 presents the demographic characteristic of public primary school teachers in Kwara State, Nigeria. On the distribution of respondents, the female participants constitute the majority group with $60(56 \%)$ while their male counterpart constitutes the least group with 48 (44\%) respondents. This indicated that there are more female teachers in public primary schools in Kwara State than their male counterparts. On the age bracket of the participants, the majority of the teachers fall within the age bracket 21-30 with 43 (40\%), followed by age bracket 31-40 with 37 (34\%) and age bracket 51-60 with 13 (12\%). The age bracket with the least representative is age 20 and below with 4 (4\%) and age bracket 41-50 with $11(10 \%)$.

The majority of the respondents are teachers from Community LGEA Primary School, Ganmo in Ifelodun Local Government Area with 19 (17\%), followed by Ayedaade Community LGEA Primary School, in Offa Local Government Area with 17 (16\%), Agbede-Share LGEA Primary School, Agbede in Moro Local Government Area with 16 (15\%), Baptist LGEA Primary School, Surulere in Ilorin West Local Government Area with 15 (14\%), Gaa-Akanbi LGEA Primary School, Gaa-Akanbi in Ilorin South Local Government Area with 14 (13\%) and Community Primary School, Apata-Kajola, Irepodun Local Government Area with 14 (13\%). KLGA Demonstration Primary school, Kaima Local Government Area has the least number of respondents with 13 (12\%). There were one head teacher and one assistant head teacher each from the seven schools, representing $7(6 \%)$ and $7(6 \%)$ respectively, while others are class teachers, representing 96 (88\%). On qualification of the respondents, the majority are Nigeria Certificate of Education (NCE) holders, representing 68 (63\%), followed by Bachelor of Education with 23 (21\%) number of participants and Postgraduate Diploma in Education with 10 (9\%) participants, while teachers with Masters of Education represent the least participants with 7 (7\%). Concerning participants' years of teaching experience, $58(54 \%)$ teachers, the majority have less than 10 years of teaching experience. Others are $19(17 \%)$ with 11 to 20 teaching experience, $16(15 \%)$ with 21-30 teaching experience and lastly $15(14 \%)$ with 31 and above teaching experience. 
Table 2: Records kept in public primary schools in Kwara State

\begin{tabular}{|c|c|c|c|c|c|c|c|c|}
\hline zis & 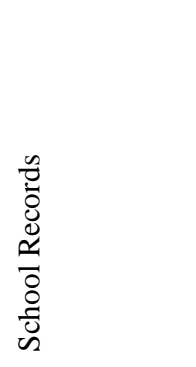 & 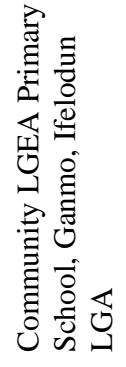 & 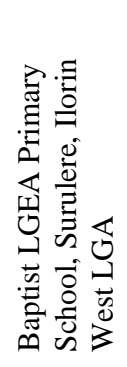 & 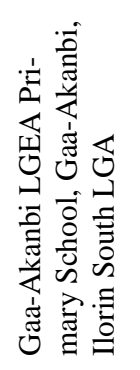 & 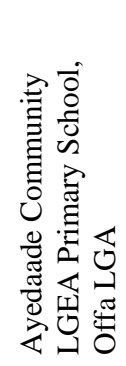 & 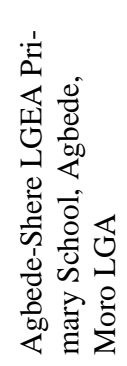 & 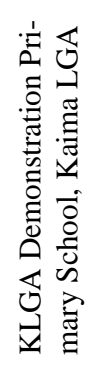 & 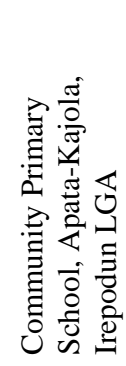 \\
\hline 1 & $\begin{array}{l}\text { Students' } \\
\text { files }\end{array}$ & $\sqrt{ }$ & $\sqrt{ }$ & $\sqrt{ }$ & $\sqrt{ }$ & $\sqrt{ }$ & $\sqrt{ }$ & $\sqrt{ }$ \\
\hline 2 & $\begin{array}{l}\text { Students' } \\
\text { report sheet }\end{array}$ & $\sqrt{ }$ & $\sqrt{ }$ & $\sqrt{ }$ & $\sqrt{ }$ & $\sqrt{ }$ & $\sqrt{ }$ & $\sqrt{ }$ \\
\hline 3 & $\begin{array}{l}\text { Attendance } \\
\text { register }\end{array}$ & $\sqrt{ }$ & $\sqrt{ }$ & $\sqrt{ }$ & $\sqrt{ }$ & $\sqrt{ }$ & $\sqrt{ }$ & $\sqrt{ }$ \\
\hline 4 & $\begin{array}{l}\text { Punishment } \\
\text { register }\end{array}$ & & & & & & & \\
\hline 5 & Logbook & $\sqrt{ }$ & $\sqrt{ }$ & $\sqrt{ }$ & $\sqrt{ }$ & $\sqrt{ }$ & $\sqrt{ }$ & $\sqrt{ }$ \\
\hline 6 & $\begin{array}{l}\text { Admission } \\
\text { register }\end{array}$ & $\sqrt{ }$ & $\sqrt{ }$ & $\sqrt{ }$ & $\sqrt{ }$ & $\sqrt{ }$ & $\sqrt{ }$ & $\sqrt{ }$ \\
\hline 7 & $\begin{array}{l}\text { Continuous } \\
\text { assessment } \\
\text { register }\end{array}$ & $\sqrt{ }$ & $\sqrt{ }$ & $\sqrt{ }$ & $\sqrt{ }$ & $\sqrt{ }$ & $\sqrt{ }$ & $\sqrt{ }$ \\
\hline 8 & $\begin{array}{l}\text { Visitors' } \\
\text { book }\end{array}$ & $\sqrt{ }$ & $\sqrt{ }$ & $\sqrt{ }$ & $\sqrt{ }$ & $\sqrt{ }$ & $\sqrt{ }$ & $\sqrt{ }$ \\
\hline 9 & $\begin{array}{l}\text { Inventory } \\
\text { Book }\end{array}$ & $\sqrt{ }$ & $\sqrt{ }$ & $\sqrt{ }$ & $\sqrt{ }$ & $\sqrt{ }$ & $\sqrt{ }$ & $\sqrt{ }$ \\
\hline $\begin{array}{l}1 \\
0\end{array}$ & $\begin{array}{l}\text { The } \\
\text { scheme of } \\
\text { work }\end{array}$ & $\sqrt{ }$ & $\sqrt{ }$ & $\sqrt{ }$ & $\sqrt{ }$ & $\sqrt{ }$ & $\sqrt{ }$ & $\sqrt{ }$ \\
\hline $\begin{array}{l}1 \\
1\end{array}$ & $\begin{array}{l}\text { School } \\
\text { time tables }\end{array}$ & $\sqrt{ }$ & $\sqrt{ }$ & $\sqrt{ }$ & $\sqrt{ }$ & $\sqrt{ }$ & $\sqrt{ }$ & $\sqrt{ }$ \\
\hline $\begin{array}{l}1 \\
2\end{array}$ & $\begin{array}{l}\text { Supervi- } \\
\text { sion report } \\
\text { file }\end{array}$ & $\sqrt{ }$ & $\sqrt{ }$ & $\sqrt{ }$ & $\sqrt{ }$ & $\sqrt{ }$ & $\sqrt{ }$ & $\sqrt{ }$ \\
\hline $\begin{array}{l}1 \\
3\end{array}$ & $\begin{array}{l}\text { Financial } \\
\text { records }\end{array}$ & $\sqrt{ }$ & $\sqrt{ }$ & $\sqrt{ }$ & $\sqrt{ }$ & $\sqrt{ }$ & $\sqrt{ }$ & $\sqrt{ }$ \\
\hline $\begin{array}{l}1 \\
4\end{array}$ & $\begin{array}{l}\text { School cal- } \\
\text { endar }\end{array}$ & $\sqrt{ }$ & $\sqrt{ }$ & $\sqrt{ }$ & $\sqrt{ }$ & $\sqrt{ }$ & $\sqrt{ }$ & $\sqrt{ }$ \\
\hline
\end{tabular}

Source: Field Survey

Table 2 presents available records that are being managed in public primary schools in Kwara State, Nigeria. Based on information received from headmasters of each 
selected public primary school, the surveyed schools mostly keep statutory records which are mandatory. Records kept are students' files, students' report sheet, attendance register, admission register, students' logbook, admission register, continuous assessment register, inventory book, school scheme of work, supervision file, financial record and school calendar. None of the surveyed schools maintains a punishment register. The study intended to draw a comparative analysis of different records kept in each public primary school, but it was observed that they all keep the same records.

Table 3: Qualities expected of a good school record management $(\mathrm{N}=180)$

\begin{tabular}{|c|c|c|c|c|c|c|c|c|c|}
\hline$z_{n}$ & $\frac{\frac{\tilde{d}}{\pi}}{\frac{\pi}{\pi}}$ & 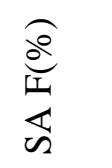 & $\widehat{\frac{8}{4}}$ & $\frac{\sqrt{e}}{z}$ & $\frac{8}{0}$ & $\frac{b^{e}}{a s}$ & $\stackrel{\Xi}{\Xi}$ & 䒕 & 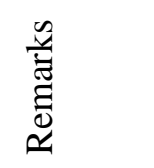 \\
\hline 1 & $\begin{array}{l}\text { The records } \\
\text { need to be com- } \\
\text { plete and usable }\end{array}$ & $\begin{array}{l}89 \\
(82 \%)\end{array}$ & $\begin{array}{l}19 \\
(18 \%)\end{array}$ & - & - & - & 4.82 & 3 & $\begin{array}{l}\text { Strongly } \\
\text { Agree }\end{array}$ \\
\hline 2 & $\begin{array}{l}\text { It should be } \\
\text { flexible to ac- } \\
\text { commodate } \\
\text { changes and } \\
\text { corrections }\end{array}$ & $\begin{array}{l}69 \\
(64 \%)\end{array}$ & $\begin{array}{l}25 \\
(23 \%)\end{array}$ & $\begin{array}{l}6 \\
(6 \%)\end{array}$ & $\begin{array}{l}3 \\
(3 \%)\end{array}$ & 1 & 4.35 & 4 & $\begin{array}{l}\text { Strongly } \\
\text { Agree }\end{array}$ \\
\hline 3 & $\begin{array}{l}\text { It should be } \\
\text { elaborate and } \\
\text { comprehensible }\end{array}$ & $\begin{array}{l}74 \\
(69 \%)\end{array}$ & $\begin{array}{l}26 \\
(24 \%)\end{array}$ & $\begin{array}{l}8 \\
(7 \%)\end{array}$ & - & - & 3.87 & 5 & Agree \\
\hline 4 & $\begin{array}{l}\text { Information pre- } \\
\text { sented therein } \\
\text { should be accu- } \\
\text { rate, reliable and } \\
\text { timely }\end{array}$ & $\begin{array}{l}98 \\
(91 \%)\end{array}$ & $\begin{array}{l}10 \\
(9 \%)\end{array}$ & - & - & - & 4.91 & 1 & $\begin{array}{l}\text { Strongly } \\
\text { Agree }\end{array}$ \\
\hline 5 & $\begin{array}{l}\text { The chosen stor- } \\
\text { age facility } \\
\text { should guaranty } \\
\text { easy and poster- } \\
\text { ity access to in- } \\
\text { formation }\end{array}$ & $\begin{array}{l}95 \\
(88 \%)\end{array}$ & $\begin{array}{l}13 \\
(12 \%)\end{array}$ & - & - & - & 4.88 & 2 & $\begin{array}{l}\text { Strongly } \\
\text { Agree }\end{array}$ \\
\hline & $\begin{array}{l}\text { Mean Variable } \\
\text { Score }\end{array}$ & & & & & & 4.57 & & \\
\hline
\end{tabular}

Source: Field Survey

Table 3 presents qualities expected of school records. The majority of the participants affirmed the five variables used in measuring good quality, whereas the mean variable score benchmark is $(\mathrm{X}=4.57)$ and only three from the five variables score above 
the benchmark, that information presented on the record should be accurate, reliable and timely was ranked first with mean score $(X=4.91)$, followed by a storage facility to foster easy access for posterity with $(\mathrm{X}=4.88)$ and need for a record to be complete and usable with mean score $(X=4.82)$, that school records should be elaborate and comprehensible score the least mean score $(\mathrm{X}=3.87)$ followed by records being flexible to accommodate changes and correction with mean score $(X=4.35)$.

Table 4: Effectiveness of record-keeping on learning progress of schoolchildren

\begin{tabular}{|c|c|c|c|c|c|c|c|c|c|}
\hline$\underset{\sim}{z}$ & $\begin{array}{l}\frac{\infty}{\pi} \\
\frac{\pi}{\pi} \\
\frac{\pi}{\pi} \\
>\end{array}$ & $\underset{\sim}{\mathbb{S}}$ & $\ll$ & z & D & $\theta$ & $\sum_{\Sigma}^{\Xi}$ & 䒕 & 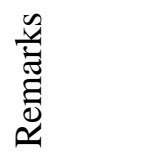 \\
\hline 1 & $\begin{array}{l}\text { Record keep- } \\
\text { ing enable } \\
\text { teacher and } \\
\text { parent to keep } \\
\text { track of } \\
\text { schoolchildren } \\
\text { learning pro- } \\
\text { gress }\end{array}$ & $\begin{array}{l}76 \\
(70 \%)\end{array}$ & $\begin{array}{l}32 \\
(30 \%)\end{array}$ & - & - & - & 4.70 & 3 & $\begin{array}{l}\text { Strongly } \\
\text { Agree }\end{array}$ \\
\hline 2 & $\begin{array}{l}\text { Student rec- } \\
\text { ords provide } \\
\text { information on } \\
\text { students' per- } \\
\text { formance in } \\
\text { school }\end{array}$ & $\begin{array}{l}88 \\
(81 \%)\end{array}$ & $\begin{array}{l}18 \\
(17 \%)\end{array}$ & $\begin{array}{l}2 \\
(2 \%)\end{array}$ & - & - & 4.80 & 1 & $\begin{array}{l}\text { Strongly } \\
\text { Agree }\end{array}$ \\
\hline 3 & $\begin{array}{l}\text { School records } \\
\text { to aid in } \\
\text { achieving edu- } \\
\text { cational goals } \\
\text { and objectives }\end{array}$ & $\begin{array}{l}72 \\
(67 \%)\end{array}$ & $\begin{array}{l}22 \\
(20 \%)\end{array}$ & $\begin{array}{l}8 \\
(7 \%)\end{array}$ & $\begin{array}{l}5 \\
(5 \%)\end{array}$ & $\begin{array}{l}1 \\
(1 \%)\end{array}$ & 4.47 & 4 & Agree \\
\hline 4 & $\begin{array}{l}\text { School records } \\
\text { are an im- } \\
\text { portant educa- } \\
\text { tional tool for } \\
\text { effective plan- } \\
\text { ning and ad- } \\
\text { ministration }\end{array}$ & $\begin{array}{l}56 \\
(52 \%)\end{array}$ & $\begin{array}{l}38 \\
(35 \%)\end{array}$ & $\begin{array}{l}7 \\
(6 \%)\end{array}$ & $\begin{array}{l}4 \\
(4 \%)\end{array}$ & $\begin{array}{l}3 \\
(3 \%)\end{array}$ & 4.30 & 7 & Agree \\
\hline 5 & $\begin{array}{l}\text { School record } \\
\text { engenders } \\
\text { teaching com- } \\
\text { petencies }\end{array}$ & $\begin{array}{l}53 \\
(49 \%)\end{array}$ & $\begin{array}{l}35 \\
(32 \%)\end{array}$ & $\begin{array}{l}9 \\
(8 \%)\end{array}$ & $\begin{array}{l}6 \\
(6 \%)\end{array}$ & $\begin{array}{l}5 \\
(5 \%)\end{array}$ & 4.16 & 8 & Agree \\
\hline 6 & School record & 66 & 28 & 6 & 4 & 4 & 4.37 & 6 & Agree \\
\hline
\end{tabular}




\begin{tabular}{|c|c|c|c|c|c|c|c|c|c|}
\hline & $\begin{array}{l}\text { enhances ef- } \\
\text { fective guid- } \\
\text { ance and coun- } \\
\text { seling for } \\
\text { schoolchildren }\end{array}$ & $(61 \%)$ & $(25 \%)$ & $(6 \%)$ & $(4 \%)$ & $(4 \%)$ & & & \\
\hline 7 & $\begin{array}{l}\text { Continuous } \\
\text { education is } \\
\text { enhanced, } \\
\text { when proper } \\
\text { records are } \\
\text { kept. }\end{array}$ & $\begin{array}{l}65 \\
(60 \%)\end{array}$ & $\begin{array}{l}32 \\
(29 \%)\end{array}$ & $\begin{array}{l}5 \\
(5 \%)\end{array}$ & $\begin{array}{l}4 \\
(4 \%)\end{array}$ & $\begin{array}{l}2 \\
(2 \%)\end{array}$ & 4.43 & 5 & Agree \\
\hline 8 & $\begin{array}{l}\text { To effect posi- } \\
\text { tive change, } \\
\text { pupil strength } \\
\text { and weakness } \\
\text { are judged by } \\
\text { their school } \\
\text { academic rec- } \\
\text { ord }\end{array}$ & $\begin{array}{l}81 \\
(75 \%)\end{array}$ & $\begin{array}{l}25 \\
(23 \%)\end{array}$ & $\begin{array}{l}2 \\
(2 \%)\end{array}$ & - & - & 4.73 & 2 & $\begin{array}{l}\text { Strongly } \\
\text { Agree }\end{array}$ \\
\hline & $\begin{array}{l}\text { Variable Mean } \\
\text { Score }\end{array}$ & & & & & & 4.50 & & \\
\hline
\end{tabular}

Source: Field Survey

Table 4 presents the impacts of school record management on the academic performance of schoolchildren in public primary schools in Kwara State. The majority of the participants agree with the eight variables used in measuring the importance of record management on pupil academic performance. The variable mean score benchmark is $(\mathrm{X}=4.50)$, whereas only three out of the eight variables scored above the variable mean score. Student records provide information on students' performance in school with mean score $(X=4.80)$ scored the highest mean variable, followed by pupil strength and weakness are judged by their school academic record to effect positive change with mean score $(X=4.73)$ and record-keeping enable teacher and parent to keep track of schoolchildren learning progress with mean score $(X=4.70)$. School records aid in achieving educational goals and objectives with a mean score $(X=4.47)$ and continuous education is enhanced, when proper records are kept with a mean score $(X=4.43)$ that are not far below the mean variable score. School record engenders teaching competencies score the least mean score of $(X=4.16)$, followed by school records are important educational tools for effective planning and administration with mean score $(X=4.30)$ and School record enhances effective guidance and counseling for schoolchildren with mean score $(X=4.37)$, that ranked seventh and sixth respectively. 
Table 5: Constraints to effective record management in public primary schools in Kwara

\begin{tabular}{|c|c|c|c|c|c|c|c|c|c|}
\hline \multicolumn{10}{|c|}{ State } \\
\hline$z_{i s}$ & $\begin{array}{l}\frac{\mathscr{\theta}}{\pi} \\
\frac{\pi}{3} \\
>\end{array}$ & $\frac{8}{\sqrt[8]{4}}$ & $\frac{\overparen{d}}{\sqrt{2}}$ & 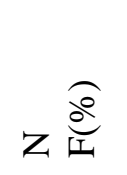 & $a \frac{\widehat{d}}{a}$ & $\frac{\partial}{a}$ & $\stackrel{\Xi}{\Xi}$ & 䒕 & 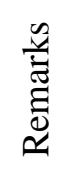 \\
\hline 1 & $\begin{array}{l}\text { Lack of rec- } \\
\text { ord keeping } \\
\text { culture }\end{array}$ & $\begin{array}{l}27 \\
(25 \%)\end{array}$ & $\begin{array}{l}26 \\
(24 \%)\end{array}$ & $\begin{array}{l}19 \\
(18 \%)\end{array}$ & $\begin{array}{l}25 \\
(23 \%)\end{array}$ & $\begin{array}{l}11 \\
(10 \%)\end{array}$ & 3.31 & 3 & 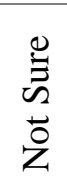 \\
\hline
\end{tabular}

\begin{tabular}{|c|c|c|c|c|c|c|c|c|c|}
\hline 2 & $\begin{array}{l}\text { Records are } \\
\text { still stored } \\
\text { manually in } \\
\text { files, shelves } \\
\text { and cabinets }\end{array}$ & $\begin{array}{l}73 \\
(68 \%)\end{array}$ & $\begin{array}{l}20 \\
(18 \%)\end{array}$ & $\begin{array}{l}2 \\
(2 \%)\end{array}$ & $\begin{array}{l}8 \\
(7 \%)\end{array}$ & $\begin{array}{l}5 \\
(5 \%)\end{array}$ & 4.37 & 2 & $\frac{\mathbb{D}}{\stackrel{D}{0}}$ \\
\hline 3 & $\begin{array}{l}\text { Administra- } \\
\text { tive staff } \\
\text { lack the } \\
\text { competency } \\
\text { to effectively } \\
\text { manage the } \\
\text { school rec- } \\
\text { ords }\end{array}$ & $\begin{array}{l}15 \\
(14 \%)\end{array}$ & $\begin{array}{l}23 \\
(21 \%)\end{array}$ & $\begin{array}{l}13 \\
(12 \%)\end{array}$ & $\begin{array}{l}37 \\
(34 \%)\end{array}$ & $\begin{array}{l}20 \\
(19 \%)\end{array}$ & 2.78 & 5 & 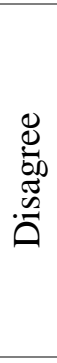 \\
\hline 4 & $\begin{array}{l}\text { Most records } \\
\text { are not easily } \\
\text { accessible }\end{array}$ & $\begin{array}{l}24 \\
(22 \%)\end{array}$ & $\begin{array}{l}28 \\
(26 \%)\end{array}$ & $\begin{array}{l}11 \\
(10 \%)\end{array}$ & $\begin{array}{l}31 \\
(29 \%)\end{array}$ & $\begin{array}{l}14 \\
(13 \%)\end{array}$ & 3.16 & 4 & $\begin{array}{l}0 \\
\vdots \\
\tilde{n} \\
\vdots \\
z\end{array}$ \\
\hline
\end{tabular}

\begin{tabular}{|c|c|c|c|c|c|c|c|c|}
\hline 5 & $\begin{array}{l}\text { Most records } \\
\text { are old and } \\
\text { crying for } \\
\text { weeding due } \\
\text { to lack of } \\
\text { preservative } \\
\text { measures }\end{array}$ & $\begin{array}{l}75 \\
(69 \%)\end{array}$ & $\begin{array}{l}17 \\
(16 \%)\end{array}$ & $\begin{array}{l}5 \\
(5 \%)\end{array}$ & $\begin{array}{l}7 \\
(6 \%)\end{array}$ & $\begin{array}{l}4 \\
(4 \%)\end{array}$ & 4.41 & 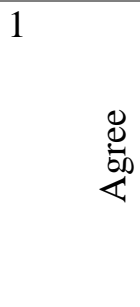 \\
\hline & $\begin{array}{l}\text { Mean Varia- } \\
\text { ble Score }\end{array}$ & & & & & & 3.61 & \\
\hline
\end{tabular}

Source: Field Survey

Table 5 presents constraints to effective school record management in public primary schools in Kwara State. Out of the five variables used in measuring constraints, 
participants only agree with two constraints, are not sure of the other two and disagree with one. The mean variable score benchmark is $(X=3.61)$, while only two variables score above the benchmark. That most records are old and crying for weeding due to lack of preservative measures score the highest mean score with $(X=4.41)$, followed by records still being stored manually in files, shelves and cabinets with mean score $(X=4.37)$, which ranked second and above the benchmark. Participants disagree with the notion that administrative staff lacks the competency to effectively manage the school records, and the variable score the least mean score with $(\mathrm{X}=2.78)$. Lack of record-keeping culture and the notion that records are not easily accessible are two variables participants are indifferent about, which mean score is $(\mathrm{X}=3.31)$ and $(\mathrm{X}=3.16)$ respectively.

\section{Discussion of Findings}

An investigation into what records are kept in public primary schools in Kwara State indicated that all statutorily required records are kept. Records kept are students' files, students' report sheet, attendance register, admission register, students' logbook, admission register, continuous assessment register, inventory book, school scheme of work, supervision file, financial record and school calendar. None of the surveyed schools maintain a punishment register. In comparison, the surveyed seven public primary schools keep the same statutory and non-statutory records

On the quality of a good school record management, top in the ranking are information on the records should be accurate, reliable and timely, easily accessible, stored on an enduring facility that can pass the test of time, and more so, the information presented therein should be complete and usable. Other qualities were that the records should be comprehensible and flexible to allow for changes and corrections if needs arise.

Results of findings on the importance of record-keeping on schoolchildren's learning progress, showed evidence that students' performance assessments are judged by records of students' report sheets, continuous assessment books, attendance registers and many more. With the student performance record, parents, teachers and other educational stakeholders can easily keep track of students' learning progress to effect positive change if need be.

Result of findings on constraints to effective record management in Kwara State, Nigeria, pinpointed majorly on two challenges, one of which is that most records are old, due for weeding as a result of lack of preservation measures put in place and also that records are still stored manually in paper files, shelves and cabinets. The notion that the administrative staff is incompetent is disputed, while a strong stand could not be made as to whether truly teachers lack record-keeping culture and that most record is not easily accessible. 


\section{Conclusion}

The surveyed seven public primary schools from seven different local government areas in Kwara State are under the Kwara State Universal Basic Education Board; hence they keep the same school and student records. It is evident from the study that public primary school teachers in Kwara State, Nigeria are familiar with some principles of record-keeping and also proficient in most of the operational procedures of keeping accurate records that is of utmost importance to good practice of continuous assessment on which the National Policy on Education stipulated that the progression of Nigerian children should be based. The relevancy of record-keeping lies in it utilizing in form of a continuous assessment for monitoring pupils' learning progress, and for other purposes such as medium for the assessment of effectiveness of teaching methods, educational programs and instructional materials. School record-keeping enable school administrators to have background information of students learning progress and school progression that provide justification for certain needs and also to extend the memory by which schools can pass on their learning achievement to the future generation. The content and quality of the school record can serve as a direct reflection of the amount of work that has been expended on the school. Also, records help school administrators and parents to keep a concise and accurate timeline of events in the life of pupils.

\section{Recommendations}

The succeeding suggestions are made in the light of the result ensuing from the research findings:

5. Record maintenance, retrieval and preservation constitute a major setback in school record management, hence, a clerical officer or store officers should be designated to carry out maintenance services.

6. Since equipment and facilities needed for the safekeeping of records are not available, most importantly, effort needs to be geared toward digitizing school records and while those yet to be digitized should be kept in a locked file, only to be withdrawn by those privilege to the information presented therein.

7. Teachers should be given regular training on record keeping and retrieval and also be encouraged to imbibe record-keeping culture.

8. Head teachers should ensure that all statutory records are duly filled by appropriate individuals and kept for evidence and records purposes.

9. As none of the surveyed public primary school keeps punishment register, even so, corporal punishment is part of students' leaning process, henceforth, for avoidance of all doubt, school heads should endeavor to maintain punishment registers to record 
punishment awarded erring students.

\section{References}

Alabi, A.O. (2017). Record keeping for the effective administration of secondary schools. Journal of Public Administration and Governance, 7(2), 66-74. Retrieved from: https://www.macrothink.org/journal/index.php/jpag/article/view/11182/pdf

Ali, s., Haider, Z., Munir, F., Khan, H. \& Ahmed, A. (2013). Factors contributing to the students' academic performance: A case study of Islamia University SubCampus. American Journal of Educational Research, 1(18), 283-289.

Amadi, N. (2014). Organization and management of schools in Nigeria: Past and present. Lagos: Vitaman Educational Books.

Amie-Ogan, T.O. \& Tagbo, S. (2021). Principals' record-keeping practices for enhanced administrative effectiveness in public senior secondary schools in Rivers State. International Journal of Innovative Information Systems, 9(3), 7888. Retrieved from: https://seahipaj.org/journals-ci/sept2021/IJIISTR/full/IJIISTR-S-8-2021.pdf

Eshetu, A.A. (2014). Indiscipline problems of high school, Addis Ababa, Ethiopia. Journal of Education and Practice, 5(37), 23-28. Retrieved from: https://core.ac.uk/download/pdf/234636703.pdf

Farooq, A.I.T., Chaudhry, M., Shafiq, M. \& Berhanu, G. (2011). Factors affecting students' quality of academic performance: A case study of secondary school level. Journal of Quality and Technology Management, 7, 1-14.

Federal Government of Nigeria (2004). National Policy on Education (revised edition). Abuja: NERDC

Federal Government of Nigeria (2013). National Policy on Education (6th Ed.). Abuja: NERDC

Ibara, E.C. (2010). Perspectives in educational administration. Port Harcourt: Rodi Printing and Publishing.

Khan, R.M.A., Iqbal, N., \& Tasneem, S. (2015). The influence of parent's educational level on secondary school student's academic achievement in District Rajanpur. Journal of Education and Practice, 6(16), 76-79. Retrieved from: https://files.eric.ed.gov/fulltext/EJ1079955.pdf

Koko, M.N., \& Nwiyi, G.U. (2019). Educational Management: A practical perspective. Port Harcourt: Rodi Printing \& Publishing.

Norad, A. \& Abdullah, B. (2016). Academic performance of senior secondary school students: Influence of parental encouragement and school environment. Rupkatha Journal on Interdisciplinary Studies in Humanities, 8(2), 12-19. Retrieved from: https://rupkatha.com/V8/n2/02_Academic_Performance.pdf

Ololube, N.P. (2011). Education and society: An interactive approach. Owerri: Spring Field Publishers.

Ololube, N.P. (2013). Educational Management, planning and supervision: Model for effective implementation. Owerri: Spring Field Publishers. 
Rono, R. (2013). Factors affecting pupil's performance in public primary schools at Kenya Certificate of Primary Education Examination (KCPE). A thesis submitted to the College of Education and External Studies, University of Nairobi, Kenya.

Singh, S.P., Malik, S. \& Sigh, p. (2016). Factors affecting academic performance of students. Indian Journal of Research, 5(4), 176-178. Retrieved from: https://www.worldwidejournals.com/paripex/article/factors-affecting-academicperformance-of-students/Mjk1MzE=/

Uzoho, K.C. (2006). Record keeping practice of secondary school principals. Unpublished M.Ed. Thesis. Department of Education, Abia State University, Abia. 